\title{
No Longer Clinically Benefiting
}

National Cancer Institute

\section{Source}

National Cancer Institute. No Longer Clinically Benefiting. NCI Thesaurus. Code C156551.

An indication that a treatment or therapy was changed or discontinued because it is no

longer clinically beneficial to the subject or patient, based on the primary therapeutic

objective for which it is being administered and assessed. (T rial Design and Objectives for Castration-Resistant Prostate Cancer: Updated Recommendations From the Prostate Cancer Clinical Trials Working Group 3. Scher HI, Morris MJ, Stadler WM, et al.; Prostate Cancer Clinical Trials Working Group 3. J Clin Oncol. 2016 Apr 20;34(12):1402-18.) 